\title{
A study on the relationship between commitment of club activity and vocational readiness among university students
}

\author{
Takashi Mizusawa $^{\text {a, }}$, Yasuyuki Hochi ${ }^{\mathrm{a}}$ and Motoki Mizuno ${ }^{\mathrm{a}}$ \\ a Juntendo University Graduate School of Health and Sports Science, 1-1, Hiragagakuendai Inzai,Chiba, 270- \\ 1695 Japan
}

\begin{abstract}
The purpose of this study was to clarify the relationship between commitment of club activities and the vocational readiness among juniors at university. In this study, organizational commitment questionnaire (Mowday, 1979) and vocational readiness scale (Wakabayashi, Goto, and Shinkai, 1983) were tested with 178 (120 men, 58 women) juniors at one physical education university in the metropolitan area. According to correlation analysis, the relation between commitment of club activities and the vocational readiness was positive significant correlation $(\mathrm{r}=.303, \mathrm{p}<.01)$. Moreover, we executed $\mathrm{t}$-test. As the combined results, this study provided the following three conclusions; 1) Vocational readiness score of students who belonged to the club were higher than that of other students. 2) Vocational readiness score of students who were committed to club activities were higher than that of students with low commitment to club activities. 3) Students who were committed to club activities tended to increase the score of vocational readiness. It was not able to be declared that there were positive influences of the club activities in university education from the viewpoint of vocational readiness acquisition. Therefore, it is necessary to consider what the club activities should be from the viewpoint of university student's career education.
\end{abstract}

Keywords: career development, job hunting, physical education university

\section{Introduction}

Recently, along with the affairs of administration for Japanese company, employment by some of company is tight for Japanese junior. The class of 2011's informal decision rate was $91.1 \%$ that is the lowest rate since investigation had started 1996. In these society, the company tend to select the members of the recruit more carefully and start early the employment campaign because their want to employ an excellent student. Therefore, many students worry that club activity and job hunting going together and they have a lot of anxiety for their future. The member of some club activities who especially athletic oriented one is demanded to commitment for their club and they are difficult to secure of time to job hunting.
Therefore, the purpose of this study was to consider the right or wrong viewpoint of club activities at university education by clarify the relationship between commitment of club activities and the vocational readiness among juniors at university.

\section{Practice and innovation (methods)}

(1)Questionnaire survey was carried out targeting to 178 (120 men, 58 women) juniors at one physical education university in the metropolitan area from November $8^{\text {th }}$ to $16^{\text {th }}$ in 2010. And (2) Organizational Commitment Questionnaire (Mowday et al, 1979) was used to clarify degree of the commitment of club activities. Moreover, (3) to clarify the degree of vocational readiness of junior, vocational readiness scale

${ }^{*}$ Corresponding author. E-mail: mizusawa0418_sob@yahoo.co.jp 
(Wakabayashi, Goto, and Shikanai, 1983) was used for them. The average age of the participants was 20.89 years $(\mathrm{SD}= \pm 0.89)$.

\section{Findings and Discussion}

\subsection{The Relationship between club style and Vocational Readiness}

We divide the student into two groups that belong to formal club and other. Next, we executed t-test between these two groups with subscale of vocational readiness. As the result, belong to not formal club student's score at "concern about vocation", "definite view", and "subjectivity" were higher than other's (Table1).

Table1

The relationship between club style and vocational readiness

\begin{tabular}{|c|c|c|c|c|c|}
\hline & \multicolumn{4}{|c|}{ The kind of club activity } & \multirow[b]{3}{*}{$\mathrm{t}$} \\
\hline & \multicolumn{2}{|c|}{$\begin{array}{l}\text { B elong to } \\
\text { form al club }\end{array}$} & \multicolumn{2}{|c|}{$\begin{array}{l}\text { B elong to inform al } \\
\text { club or not others }\end{array}$} & \\
\hline & $\mathrm{m}$ ean & $\mathrm{SD}$ & m ean & $\mathrm{SD}$ & \\
\hline concem about vocation & 18.17 & 2.84 & 19.51 & 2.51 & $5.41 *$ \\
\hline definite view & 17.38 & 3.02 & 18.89 & 2.87 & $6.00 *$ \\
\hline practical view & 16.49 & 1.84 & 16.24 & 1.74 & 0.46 n.s. \\
\hline subjectiv ity & 19.02 & 2.95 & 20.48 & 2.18 & $6.29 *$ \\
\hline objectivity of ow n know ledge & 17.29 & 1.87 & 17.41 & 1.91 & 0.09 n.s. \\
\hline
\end{tabular}

\subsection{The Relationship between the Commitment and Vocational Readiness among formal club}

First, we calculated commitment score at belong to formal club activities student. Second, we classify two groups based on the mean of OCQ score. For another, we executed t-test between high and low score group of OCQ with subscale of vocational readiness. As the result, high score group's score at "concern about vocation" and "definite view" were higher than other's (Table2).

Table2

The relationship between commitment and vocational readiness among formal club

\begin{tabular}{|c|c|c|c|c|c|}
\hline & \multicolumn{4}{|c|}{ Com m itm ent of form al club } & \multirow[b]{3}{*}{$\mathrm{t}$} \\
\hline & \multicolumn{2}{|c|}{$\begin{array}{c}\text { High score goroup } \\
\text { of } 0 \mathrm{CQ} \\
\end{array}$} & \multicolumn{2}{|c|}{$\begin{array}{c}\text { Low score goroup } \\
\text { of } \mathrm{OCQ}\end{array}$} & \\
\hline & m ean & SD & m ean & SD & \\
\hline concem about vocation & 18.89 & 2.64 & 17.42 & 2.86 & $9.12 *$ \\
\hline definite view & 17.95 & 2.91 & 16.79 & 3.05 & $4.89 *$ \\
\hline practical view & 16.75 & 1.95 & 16.22 & 1.69 & $2.74 \mathrm{n} . \mathrm{s}$ \\
\hline sub jectivity & 19.37 & 2.98 & 18.65 & 2.89 & 1.97 n.s \\
\hline objectivity of ow n know ledge & 17.33 & 1.7 & 17.25 & 2.05 & $0.06 \mathrm{n.s}$ \\
\hline
\end{tabular}

\subsection{The Relationship between Commitment and Vocational Readiness}

First, we calculated commitment score at belong to formal club and informal club students. Second, we classify two groups based on the mean of OCQ score. For another, we executed t-test between high and low score group of OCQ with subscale of vocational readiness. As the result, high score group's score of "concern about vocation", and "subjectivity" were higher than another (Table3).

Table3

The relationship between commitment and vocational readiness

\begin{tabular}{|c|c|c|c|c|c|}
\hline & \multicolumn{4}{|c|}{ Comm itm ent of whole club activity } & \multirow[b]{3}{*}{$\mathrm{t}$} \\
\hline & \multicolumn{2}{|c|}{$\begin{array}{c}\mathrm{H} \text { igh score goroup } \\
\text { of } \mathrm{OCQ}\end{array}$} & \multicolumn{2}{|c|}{$\begin{array}{c}\text { Low score goroup } \\
\text { of } 0 \mathrm{CQ}\end{array}$} & \\
\hline & m ean & SD & average & SD & \\
\hline concem about vocation & 18.61 & 2.72 & 17.55 & 3.06 & $2.26 *$ \\
\hline definite view & 17.82 & 3.04 & 17.25 & 2.99 & 1.12 n.s. \\
\hline practical v iew & 16.51 & 1.88 & 16.14 & 1.62 & 1.22 n.s. \\
\hline subjectivity & 19.46 & 2.91 & 18.5 & 2.87 & $2.00 *$ \\
\hline objectivity of ow nnow ledge & 17.39 & 1.93 & 16.9 & 2 & 1.51 n.s. \\
\hline
\end{tabular}

\subsection{The Correlation coefficient between Organizational Commitment Questionnaire and Vocational Readiness scale}

According to correlation analysis, the relation between commitment to club activities and the vocational readiness was positive significant correlation $(\mathrm{r}=.303, \mathrm{p}<.01)$ (Table4).

Table 4

Correlation coefficient between OCQ and Vocational Readiness OCQ Vocational Readiness Score

\begin{tabular}{lcc}
\hline \multicolumn{1}{c}{$0 \mathrm{CQ}$} & - & $.303 * *$ \\
Vocational Readiness Score & $.303 * *$ & - \\
\hline$* * \mathrm{p}<.01$ &
\end{tabular}

\subsection{Conclusion}

As the combined results, three following findings were led in conclusion. (1)Vocational readiness score of students who belonged to the club and not belong to some club were higher than that of other students. (2) Vocational readiness score of students who were committed to club activities were higher than that of students with low commitment to club activities. (3)Students who were committed to club activities tended to increase the score of vocational readiness. 
It was not able to be declared that there were positive influences of the club activities in university education from the viewpoint of vocational readiness acquisition. Therefore, it is necessary to consider what the club activities should be from the viewpoint of university student's career education.

\section{References}

[1] Hroi T, A Review and Reconceptualization of Organizational Commitment. "Journal of Japan University, Vol. 16, pp. 17-31, 1992.

[2] Kuratani N, Kido Y: Organizational Commitment in the Public-administration Organization: An Empirical Study on the Antecedents and Consequences of Organizational Commitment. "Journal of Sanno University, Vol.26, 2006, pp. 55-71.

[3] Mowday, R. T., Steers, R. M., \& Porter, L. W., "The Measurement of organizational commitment" , "Journal of vocational Behavior, 1979, Vol. 14, pp. 224-247.

[4] Okada Y, Participation in School-Based Extracurricular Activities and Junior High School Students' Psychosocial Adjustment to School: Effect of Type of Extracurricular Activity and Extent of Involvement. "Study of Educational Psychology, Vol.57, 2009, pp. 519-431.

[5] Steers, R. M., "Antecedents and Outcomes of Organizational Commitment", Administrative Science Quarterly, 1977, Vol. 22, pp. 46-56.

[6] Sugama M, Inoue E, Imai H, Takayasu M, Horinouchi W, Vertical Research on Occupation Readiness of Nursing Students. The Journal of Chiba Junior College, Vol.26, 2008, pp. 99-104.

[7] Wakabayashi M, Goto M, Shikanai K: Vocational Readiness and Vocational Choice Structure: On Relationships between Self Concept and Occupational Attitudes Among Female Junior College Students. Journal of Nagoya University, Vol.30, 1983, pp. 63-98. 